\title{
Effects of a commercial mussel Mytilus edulis lay on a sublittoral, soft sediment benthic community
}

\author{
Julie Smith*, Susan E. Shackley \\ School of Biological Sciences, University of Wales Swansea, Singleton Park, Swansea SA2 8PP, UK
}

\begin{abstract}
A commercial mussel Mytilus edulis lay was established in 1998 in western inner Swansea Bay (Wales, UK) in a shallow, sublittoral, high tidal energy environment, on a substrate which previously supported a diverse inshore, sand/muddy sand benthic community. Within a year of commencement of this fishery, a significant change in the species composition of the benthic community occurred, with a decrease in the number of species and in the total number of individuals. The abundance of carnivorous and deposit feeding benthic species increased, whilst the mussels outcompeted other benthic filter feeding organisms, preventing the settlement of these organisms by ingestion of the larvae, and removed other benthic organisms by physical smothering.
\end{abstract}

KEY WORDS: Mussel lay $\cdot$ Benthos $\cdot$ Community effects $\cdot$ Coastal waters

- Resale or republication not permitted without written consent of the publisher

\section{INTRODUCTION}

Mussels Mytilus edulis L. are of growing commercial importance, with increased numbers of applications for permission to site commercial mussel lays around the UK coast in shallow, sheltered, inshore environments. This method involves relaying small 'seed' mussels, taken from natural beds, onto sites (lays) where growth conditions are good and fishing by dredging is more efficient because of depth, substrate type and proximity to a port. Since the mussel seed are under fishable size a 'Several Order' has to be obtained from the government before the seed may be transferred to the commercial lay. The impact of mussel lays on the ecology, and in particular on the benthos, of the receiving area is largely unknown, which makes an accurate assessment of the potential impact of new lays impossible. The present study investigates the impact on the benthos of a mussel lay sited in an area in western inner Swansea Bay where mussels do not naturally occur.

The first commercial mussel lay in western inner Swansea Bay was established in September 1998, and since that time 3 further applications have been made for the establishment of more extensive lays in the immediate vicinity and extending over a large part of inner Swansea Bay. To date, one of these applications has been approved.
Swansea Bay is a high-energy embayment, located on the northern coastline of the Bristol Channel, with maximum depths of $20 \mathrm{~m}$ relative to chart datum (CD) and an extensive, low gradient intertidal zone (Fig. 1). The tidal current takes the form of a rectilinear, reversing offshore flow with an area of divergence on the eastern side of the embayment generating an anticlockwise gyre in inner Swansea Bay (Collins et al. 1979). In inner Swansea Bay the sediments are mainly fine and medium sand with increasing proportions of mud occurring close inshore to the west, where Mumbles Head provides protection from wave exposure and the shallow water slows the tidal currents.

\section{MATERIALS AND METHODS}

Study site. The study site $\left(51^{\circ} 35.00^{\prime} \mathrm{N}, 03^{\circ} 58.75^{\prime} \mathrm{W}\right)$ (Fig. 1) is situated in western inner Swansea Bay, at a depth of $-0.7 \mathrm{~m}$ (relative to $\mathrm{CD}$ ) within an area of substrate composed mainly of sand, which prior to the introduction of the mussel lay had remained unchanged for 2 yr (Smith 2002). The tidal currents are strong on the ebb tide and, although the area is largely protected by Mumbles Head from the prevailing southwesterly swell, it is exposed to short period wave action from the south and southeast. 


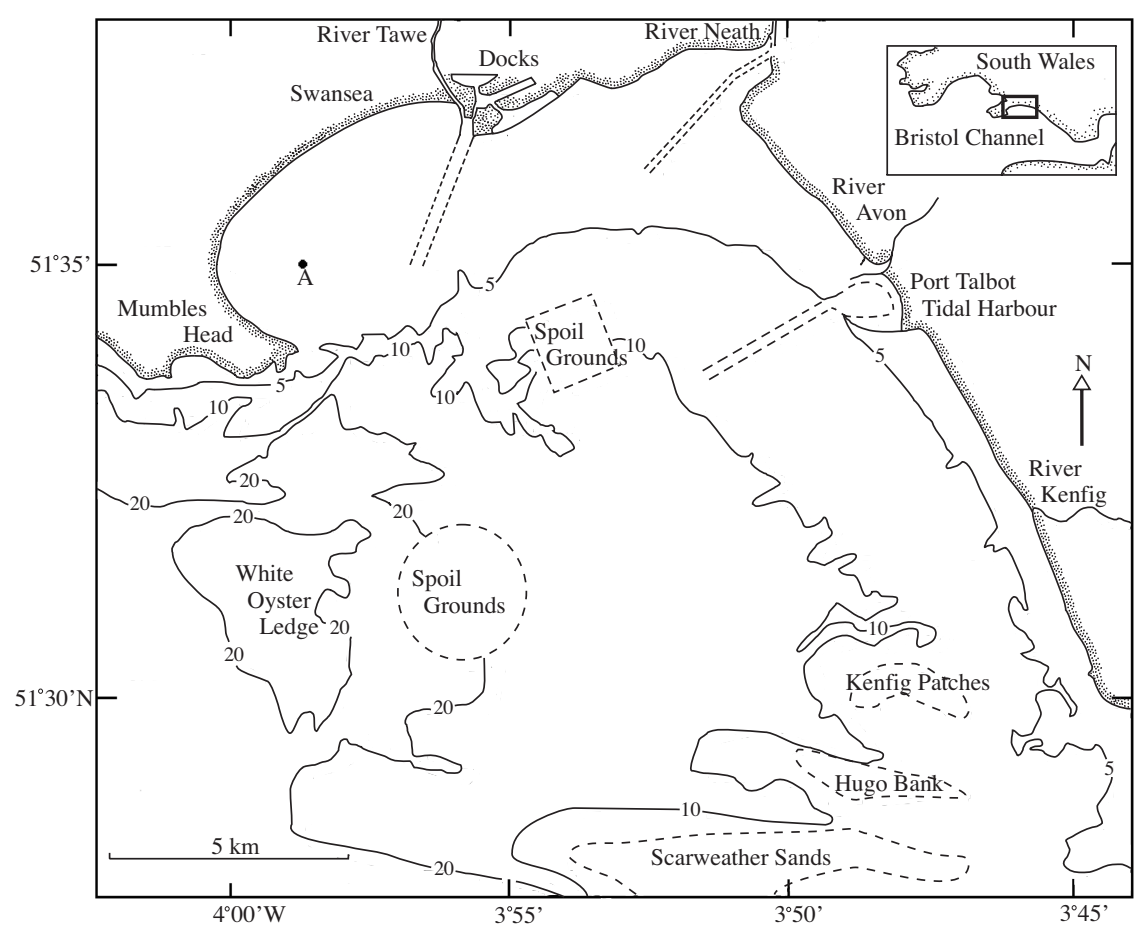

Fig. 1. Bathymetry of Swansea Bay (after Shackley \& Collins 1984), showing the location of the sampling station (A). Depths of contour lines are given in metres

\section{RESULTS}

\section{Sediment}

Prior to the introduction of the mussel lay in September 1998, the study site had a predominantly sandy substrate (91 to $99 \%$ sand: 1 to $9 \%$ mud) (Fig. 2a,b). However, with the establishment of the lay and regular, commercial harvesting of mussels thereafter, abrupt changes in sediment composition soon became apparent at the site (Fig. 2a,b). This may be indicative of the habitat change brought about by the mussel culture and the effects of harvesting mussels by dredging. Mussels were laid in September 1998, and dredged in May and August 1999.

By August and October 1999, gross changes in sediment type were apparent with sand:mud ratios ranging from 4 to $81 \%$ sand: 19 to $96 \%$ mud in August 1999 (shortly after mussel harvesting had occurred), and 15 to $96 \%$ sand : 4 to $85 \%$ mud in October 1999

Sampling strategy. The site was sampled seasonally between January 1998 and December 1999 over high water Spring tides, using a $0.1 \mathrm{~m}^{2}$ Day grab. Five replicate samples were taken from the site in accordance with the results of a pre-study 'power analysis' (Clark et al. 1997).

Treatment of samples. A sub-sample of sediment was taken from each of the 5 replicate samples at sea and the remaining sediment was sieved through a $1 \mathrm{~mm}$ mesh sieve. Sieve debris with retained fauna was preserved in $70 \%$ ethanol. Sediment samples were frozen on return to the laboratory and at a later date defrosted and analysed. Fauna were removed from the sieve debris by hand sorting, identified to species level whenever possible (using texts by Lincoln 1979, Hayward \& Ryland 1995), counted (abundance) and their wet weights recorded (biomass). Epifauna were noted and identified although their abundance could not be quantified and they were not used in subsequent statistical analyses.

Each replicate sample of sediment was wet sieved through a $63 \mu \mathrm{m}$ mesh to calculate the sand-to-mud ratio. The retained sand fraction was then oven dried at $50^{\circ} \mathrm{C}$ for $24 \mathrm{~h}$, and the dried samples were mechanically graded through a sieve stack of sieve sizes of 1000, 500, 250, 125 and $63 \mu \mathrm{m}$.

The Difference-On-Ignition (D.O.I) method of Luczak et al. (1997) was used to determine the mean organic matter content of each set of 3 replicate sediment samples. (the month of highest Mytilus edulis abundances; see Fig. 4a) (Fig. 2a,b). A parametric 2-sample $t$-test verified that there was a significant increase $(p<0.05)$ in mud content from August 1998 (no mussel lay) to August 1999 (post establishment of the lay). Consolidated clay deposits were also noted in the sediment samples of August 1999, which is possibly due to mussel harvesting by dredging, exposing underlying clay deposits.

Cumulative frequency curves for the sand fraction show that the sand was well sorted, composed of medium (26 to $62 \%$ ) and fine sand (28 to $60 \%$ ), which is typical of the sands being transported into the area. As expected, the sediment also became increasingly organically enriched as the mud content increased, with organic matter contents of 1 to $2 \%$ from January 1998 until a sudden significant increase $(p<0.05)$ occurred in August (8\%) and October (5\%) 1999 (Fig. 2c).

\section{Fauna}

Before the mussel lay was introduced, the benthic community at the study site was largely composed of polychaetes, gastropods, bivalves, amphipods and cirripeds, but was one in which polychaetes dominated (Table 1). Once the lay became established in Septem- 

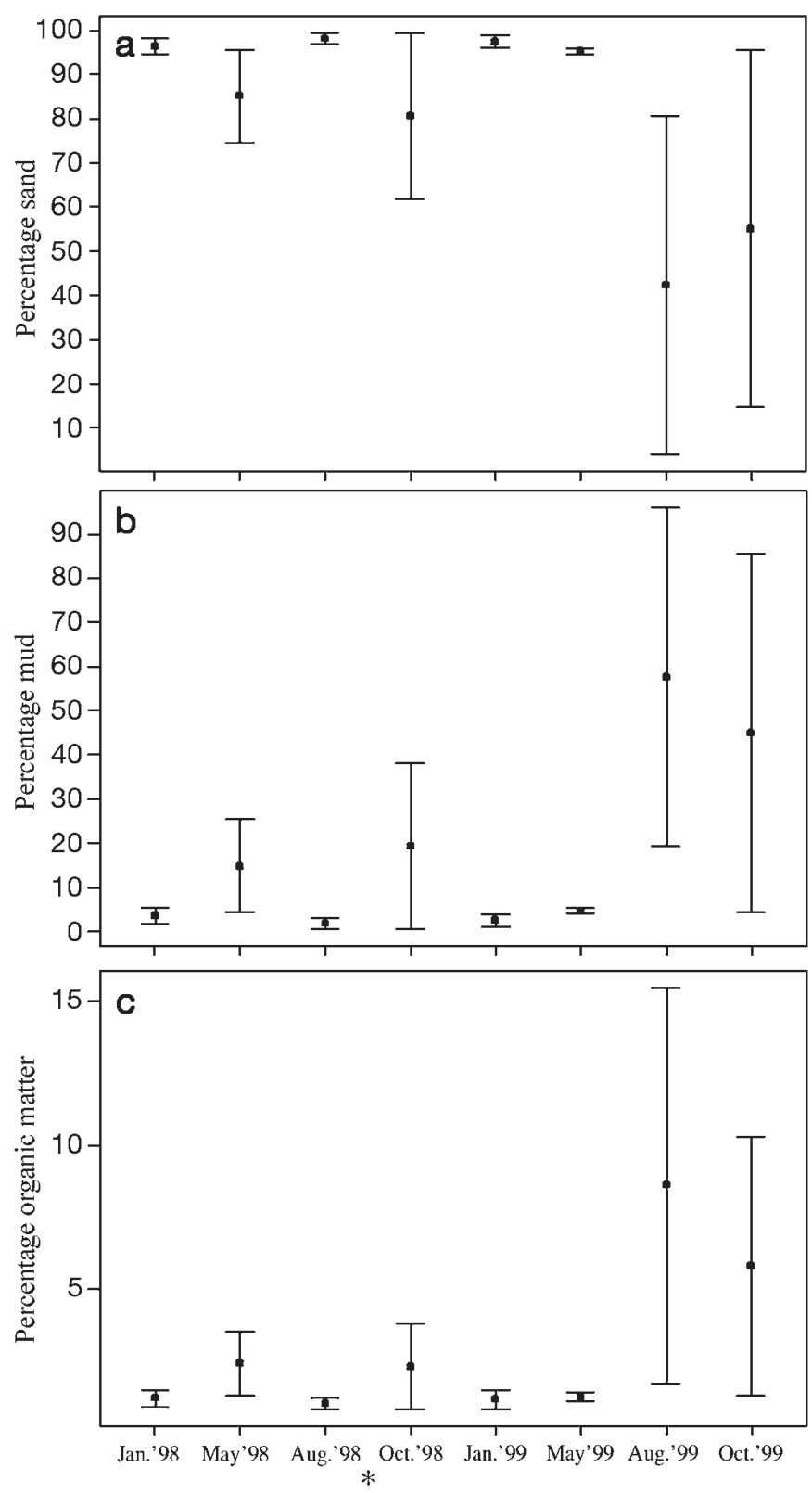

Fig. 2. Means and 95\% confidence intervals of percentage of (a) sand, (b) mud, and (c) organic matter content of sediment obtained from the study site during 1998 and 1999. *September 1998 (mussel lay established)

ber 1998, there was a significant change in the species composition of the community. Polychaetes became less dominant as the relative proportion of bivalves, amphipods, decapods, ophiuroids and mysids increased (Table 1). A 2-sample $t$-test showed that there was a significant $(p<0.05)$ decrease in the number of species and an overall decline in the total number of individuals with the establishment of the lay.

The hierarchical agglomerative method (Fig. 3) shows the existence of 5 major groups (Groups 2, 3, 4,

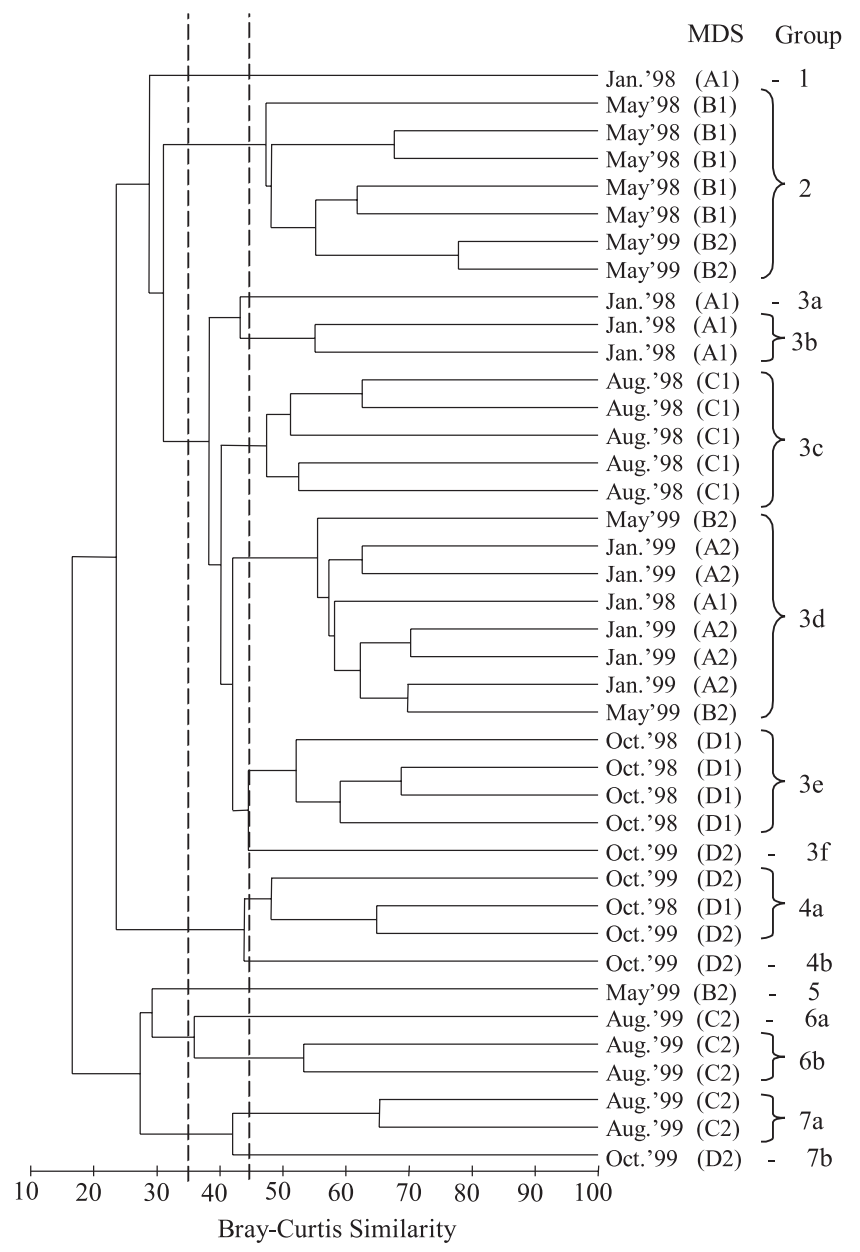

Fig. 3. Dendrogram for hierarchical clustering of the faunal abundances at the study site, using group-average clustering of Bray-Curtis similarities based on 4th root-transformed abundances

6 and 7) and 1 minor group (Group 1) of benthic species at the $35 \%$ similarity level, and the further division of Groups 3, 4, 6 and 7 into sub-groups at $45 \%$ similarity. Groups 2, 3a, 3b and 3c consist largely of samples obtained before the introduction of the mussel lay, whilst Groups 3d, 3e, 3f, 4, 6 and 7 are those samples taken after the establishment of the lay (Fig. 3). August and October 1999 are, again, the periods that are most separated from the other months sampled. Since August 1999 (Groups 6a, 6b and 7a) was a period in which there were no mussels (Fig. 4a) at the study site (as a result of mussel harvesting), separation from the other samples (Fig. 3) may reflect the effects of regular mussel harvesting on the benthic community. The separation of October 1999 from the other samples (Fig. 3) is possibly a result of this period having the highest abundances of Mytilus edulis (Fig. 4a).

The similarity percentage programme SIMPER (Clarke 1993) was used to investigate the contributions 
Table 1. Percentage of individuals from the major taxa present at the study site

\begin{tabular}{|cccccccccc|}
\hline & $\begin{array}{c}\text { Class } \\
\text { Polychaeta }\end{array}$ & $\begin{array}{c}\text { Class } \\
\text { Bivalvia }\end{array}$ & $\begin{array}{c}\text { Order } \\
\text { Amphipoda }\end{array}$ & $\begin{array}{c}\text { Order } \\
\text { Decapoda }\end{array}$ & $\begin{array}{c}\text { Class } \\
\text { Gastropoda }\end{array}$ & $\begin{array}{c}\text { Order } \\
\text { Mysidacea }\end{array}$ & $\begin{array}{c}\text { Class } \\
\text { Ophiuroidea }\end{array}$ & $\begin{array}{c}\text { Class } \\
\text { Cirripedia Pycnogonida }\end{array}$ \\
\hline Jan '98 & 49.5 & 11.3 & 4.8 & 2.2 & 25.8 & 0.0 & 0.5 & 2.2 & 3.8 \\
May'98 & 6.0 & 0.5 & 0.8 & 0.3 & 14.7 & 0.0 & 0.0 & 75.6 & 2.0 \\
Aug'98 & 66.0 & 6.0 & 7.4 & 1.6 & 11.0 & 0.5 & 0.2 & 6.7 & 0.2 \\
Oct '98 & 34.1 & 43.8 & 4.6 & 3.5 & 2.5 & 2.1 & 3.7 & 5.4 & 0.0 \\
Jan '99 & 64.1 & 31.2 & 1.2 & 3.5 & 0.0 & 0.0 & 0.0 & 0.0 & 0.0 \\
May'99 & 30.7 & 1.9 & 0.4 & 0.8 & 25.8 & 0.0 & 0.0 & 40.2 & 0.0 \\
Aug'99 & 60.0 & 0.0 & 13.3 & 0.0 & 0.0 & 6.7 & 20.0 & 0.0 & 0.0 \\
Oct '99 & 10.1 & 61.9 & 1.9 & 13.4 & 1.2 & 3.1 & 5.8 & 2.1 & 0.4 \\
\hline
\end{tabular}
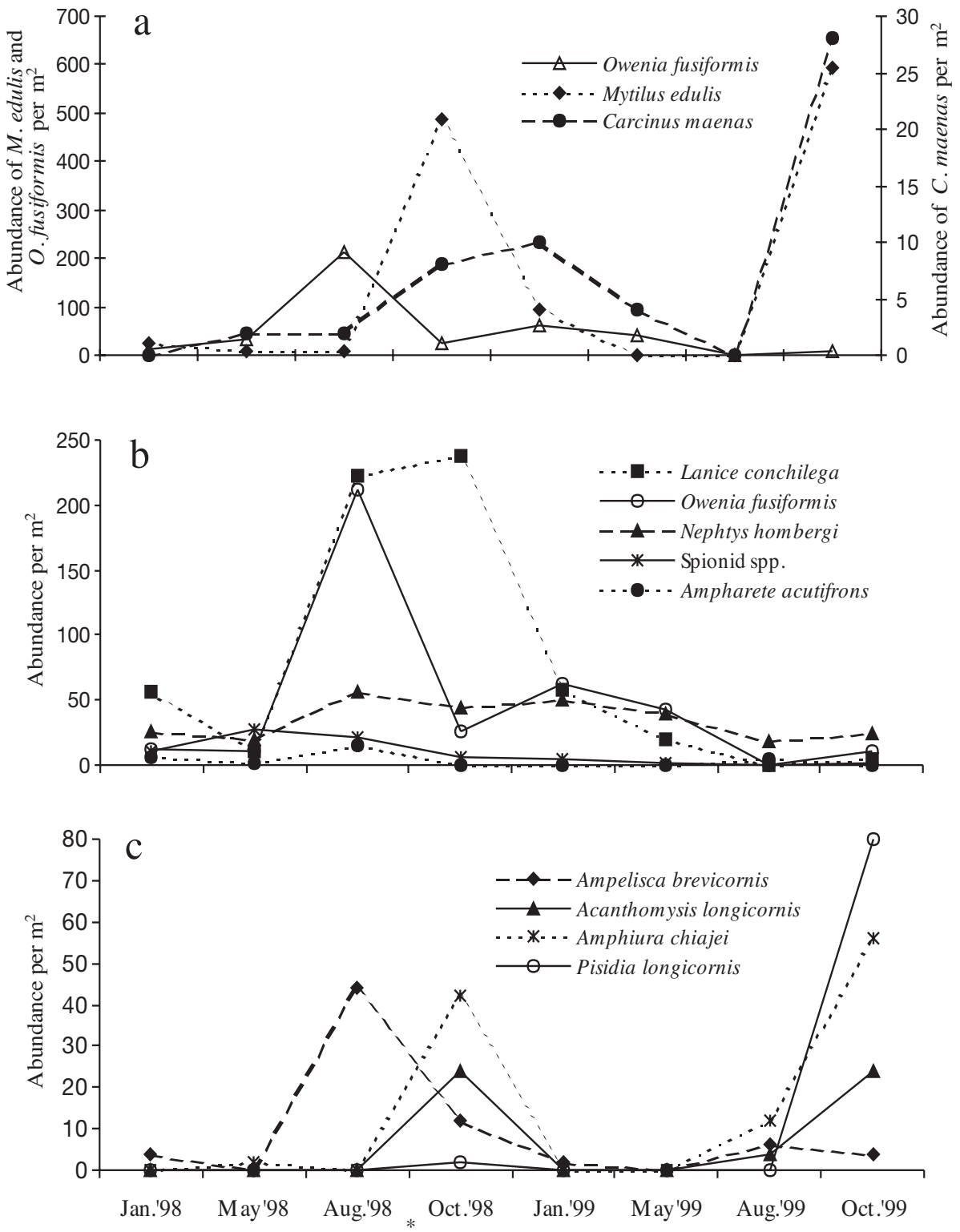

Fig. 4. Changes in the abundance of (a) Owenia fusiformis, Mytilus edulis and Carcinus maenas, (b) polychaetes and (c) crustaceans over the study period. *September 1998 (mussel lay established) of individual species to the observed dissimilarities between the 1998 and 1999 samples of winter (January), spring (May), summer (August) and autumn (October). Mytilus edulis was the principal contributor (Table 2) to the dissimilarities between the winters of 1998 and 1999. The tube-dwelling polychaete Owenia fusiformis (Delle Chiaje) was also more abundant in January 1999 than in January 1998 (Table 2), but overall it was most prevalent in August 1998 (Fig. 4a).

In contrast, the slipper limpet, Crepidula fornicata (L.) (Table 2), the barnacle Semibalanus balanoides (L.) (occurring on the shells of C. fornicata) (Table 2), the polychaetes Owenia fusiformis, Nephtys hombergi (Savigny), Ampharete acutifrons (Grube) and spionid species (Fig. 4b), and the amphipod Ampelisca brevicornis (Costa) (Fig. 4c) were more abundant before the establishment of the mussel lay. The sand mason Lanice conchilega (Pallas) was abundant in August and October 1998, but decreased in abundance from this point onwards (Fig. 4b).

The shore crab Carcinus maenas (L.) occurred in relatively low abundance but increased in abundance between January 1998 and January 1999 (Table 2), and the greater increase between October 1998 and 1999 (Fig. 4a) indicates an association between the abundance of the shore crab and the mussel Mytilus edulis. There was an association between the shore crab and $M$. edulis (Spearman rank correlation $\mathrm{r}_{\mathrm{S}}=0.725$ ) at $\mathrm{p}=0.1$. 
The porcellanid crab Pisidia longicornis (L.), mysid Acanthomysis longicornis (Milne-Edwards) and brittle star Amphiura chiajei (Forbes) did not occur at the study site until after the mussel lay had been introduced (Fig. 4c). It is, therefore, possible that their peaks in abundance in October 1998 and 1999 (Fig. 4c) are related to the increased abundances of Mytilus edulis during these same periods (Fig. 4a).

Table 2. Top 10 ranked species responsible for the observed dissimilarities between samples of winter (January), spring (May), summer (August) and autumn (October) of 1998 and 1999 and their average abundances $\left(\mathrm{m}^{-2}\right)$ and individual contribution $(\%)$ to the average dissimilarity value

\begin{tabular}{|c|c|c|c|c|}
\hline \multirow[t]{2}{*}{ Species } & \multicolumn{2}{|c|}{$\begin{array}{l}\text { Average abundance } \\
\qquad\left(1 \mathrm{~m}^{2}\right)\end{array}$} & \multirow[t]{2}{*}{$\%$} & \multirow[t]{2}{*}{$\begin{array}{l}\% \text { average } \\
\text { dissimilarity }\end{array}$} \\
\hline & Jan 1998 & Jan 1999 & & \\
\hline Mytilus edulis & 26 & 96 & 7.5 & 57.8 \\
\hline Owenia fusiformis & 12 & 62 & 5.9 & \\
\hline Crepidula fornicata & 96 & 0 & 4.5 & \\
\hline Atylus swammerdami & 10 & 0 & 4.3 & \\
\hline Carcinus maenas & 0 & 8 & 4.3 & \\
\hline Sabellid spp. & 8 & 0 & 4.2 & \\
\hline Spionid spp. & 10 & 4 & 4.2 & \\
\hline Modiolula phaseolina & 10 & 0 & 3.4 & \\
\hline Ampharete acutifrons & 6 & 0 & 3.2 & \\
\hline \multirow[t]{2}{*}{ Pagurus pubescens } & 8 & 0 & 3.2 & \\
\hline & May 1998 & May 1999 & & \\
\hline Semibalanus balanoides & 1024 & 212 & 11.2 & 65.5 \\
\hline Crepidula fornicata & 196 & 136 & 9.5 & \\
\hline Spionid spp. & 28 & 2 & 6.2 & \\
\hline Phyllodoce groenlandica & 0 & 16 & 5.3 & \\
\hline Eumida sanguinea & 0 & 14 & 4.6 & \\
\hline Owenia fusiformis & 10 & 42 & 4.6 & \\
\hline Sabellid spp. & 10 & 0 & 4.0 & \\
\hline Lanice conchilega & 10 & 20 & 3.4 & \\
\hline Nephtys hombergi & 20 & 40 & 3.3 & \\
\hline \multirow[t]{2}{*}{ Nymphon gracile } & 18 & 0 & 3.2 & \\
\hline & Aug 1998 & Aug 1999 & & \\
\hline Owenia fusiformis & 212 & 0 & 9.3 & 85.3 \\
\hline Lanice conchilega & 222 & 0 & 9,2 & \\
\hline Crepidula fornicata & 94 & 0 & 6.2 & \\
\hline Spionid spp. & 22 & 0 & 5.5 & \\
\hline Ampelisca brevicornis & 44 & 6 & 4.1 & \\
\hline Spisula subtruncata & 14 & 0 & 3.8 & \\
\hline Eumida sanguinea & 12 & 0 & 3.7 & \\
\hline Mytilus edulis & 12 & 0 & 3.4 & \\
\hline Semibalanus balanoides & 58 & 0 & 3.3 & \\
\hline \multirow[t]{2}{*}{ Ampharete acutifrons } & 16 & 4 & 3.1 & \\
\hline & Oct 1998 & Oct 1999 & & \\
\hline Lanice conchilega & 238 & 4 & 9.5 & 59.8 \\
\hline Mytilus edulis & 486 & 592 & 6.2 & \\
\hline Eumida sanguinea & 22 & 0 & 4.7 & \\
\hline Acanthomysis longicornis & 24 & 24 & 3.6 & \\
\hline Abludomelita obtusata & 28 & 0 & 3.5 & \\
\hline Aphroditid spp. & 24 & 10 & 3.5 & \\
\hline Pisidia longicornis & 22 & 96 & 3.4 & \\
\hline Amphiura chiajei & 42 & 56 & 3.3 & \\
\hline Owenia fusiformis & 26 & 10 & 3.3 & \\
\hline Cirratulid spp. & 8 & 20 & 3.3 & \\
\hline
\end{tabular}

Trophic relationships

As a consequence of the filter-feeder Mytilus edulis becoming the dominant organism (in terms of biomass) through the introduction of the lay, other benthic filterfeeders were out-competed and there was an overall decline in species which can both filter-feed and surface deposit-feed (Lanice conchilega and Owenia fusiformis), whilst the abundance of depositfeeders and carnivores increased (Fig. 5). It appears, however, that during those periods when there were no mussels (i.e. May \& August 1999) (Fig. 4a), as a result of mussel harvesting, the filter-feeders Crepidula fornicata and Semibalanus balanoides (occurring on the shells of $C$. fornicata) regained their dominance in May 1999 (Table 2), whilst the carnivorous Nephtys hombergi (Fig. 4b), and the deposit-feeders Amphiura chiajei and Ampelisca brevicornis dominated in August 1999 (Fig. 4c).

It is also possible that the tube-dwelling polychaetes, i.e. the filter-feeder/surface deposit feeders Lanice conchilega and Owenia fusiformis (Fish \& Fish 1996) (Fig. 4a,b) and the deposit-feeder Ampharete acutifrons (Martin et al. 2000) (Fig. 4b), were physically smothered by the mussel lay. The decline in the deposit feeding amphipod Ampelisca brevicornis (Nybakken 1993) (Fig. 4c) may be due to predation by increased numbers of carnivorous shore crabs Carcinus maenas (Fig. 4a) that appear to have resulted from the establishment of the mussel lay, or this species may have simply been unable to adapt to the change in habitat. The apparent occurrence of the deposit feeding brittle star Amphiura chiajei and the filter-feeding porcellanid crab Pisidia longicornis (Fish \& Fish 1996) with the establishment of the mussel lay (Fig. 4c) is possibly due to the lay providing both species with suitable substrates. That is, A. chiajei with a muddy environment and $P$. longicornis with a secondary hard bottom (Hayward \& Ryland 1995). During those periods, however, when mussels were harvested (i.e. May \& August 1999) (Fig. 4a), an overall decline was noted in both species (Fig. 4c).

\section{DISCUSSION}

Within a year of commencement of the mussel fishery in western inner Swansea Bay, there was a significant change in the species 


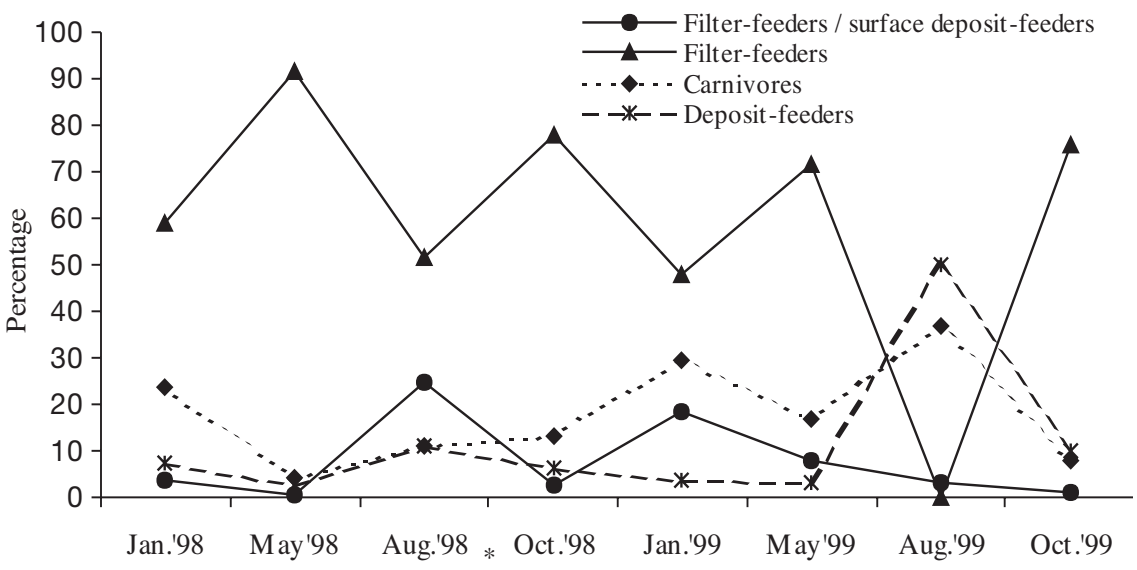

Fig. 5. Changes in the occurrence of different trophic groups at the study site. *September 1998 (mussel lay established) able to regain dominance periodically when $M$. edulis was harvested.

Increased abundances of epibenthic crustaceans (Carcinus maenas, Acanthomysis longicornis and Pisidia longicornis) and deposit-feeders (Amphiura chiajei) agrees with past studies (Commito 1987, Ragnarsson \& Raffaelli 1999, Thiel \& Ullrich 2002), which found that mussel beds bring about the recruitment of epibenthic crustaceans, whilst biodeposition provides a food source for benthic deposit-feeders. Given that shore crabs C. maenas prey on Mytilus edulis, polychaetes and crustaceans (Dankers \& Zuidema 1995, Moksnes 2002), increased numbers of crabs may, therefore, have been responsible for the decline of the composition of the benthic community at the study site, with a decrease in the number of species and in the total number of individuals. These changes may be attributable to the habitat change brought about by the mussel culture, and regular, commercial mussel harvesting preventing the age and size of the mussel patches increasing above a certain point, which would have limited the diversity of the associated invertebrates (Tsuchiya \& Nishihira 1985, 1986, Caldow et al. 2003).

It is possible that the tube-dwelling polychaetes Lanice conchilega, Owenia fusiformis, Ampharete acutifrons and those spionid species inhabiting sandy tubes were physically smothered when the lay was initially developed. However, through the creation of a structurally complex habitat, it appears that the mussel lay modified the physical environment which, in turn, shaped the associated community by providing microhabitats (e.g. for juvenile crabs; Moksnes et al. 1998, Moksnes 2002) and an organically enriched environment (Beadman et al. 2002, Saier 2002, Thiel \& Ullrich 2002). Mussel shells provided a hard substrate for sessile epibionts (Asmus \& Asmus 2002), whilst the mussels provided a supply of fine sediments (faeces and pseudofaeces), i.e. a food resource for many species, both within and underneath the mussel matrix (Tsuchiya 1980, Kröncke 1996, Ragnarsson \& Raffaelli 1999).

Mussels are extremely efficient filter-feeders (Kautsky \& Evans 1987, Granby \& Spliid 1995), and in the densities found at the study site, they would have outcompeted other filter-feeders for seston and phytoplankton (Obert \& Michaelis 1991, Beadman et al. 2002) and would have effectively prevented or reduced the settlement of these organisms by ingestion of their larvae (Cowden et al. 1984, Morgan 1992). Thus, the filter-feeding slipper limpet Crepidula fornicata was probably out-competed by Mytilus edulis, but was amphipod Ampelisca brevicornis and the polychaete Nephtys hombergi.

Furthermore, since modest reductions in mussel density increase turbulence (as a result of greater bed roughness), which enhances sediment erosion and resuspends biodeposits (Dolmer \& Frandsen 2002, Widdows et al. 2002), it is possible that mussel harvesting (by dredging) would have made the lay more vulnerable to erosion by tidal currents and storms, changed the topography and composition of the seabed, and resuspended sediment and nutrients (Dolmer \& Frandsen 2002).

\section{CONCLUSIONS}

From the present study, it can be concluded that mussel lays are biotic structures that can affect the ambient ecosystem (Asmus \& Asmus 2002). Given that inner Swansea Bay is an important nursery ground for juvenile flatfish (Mignot 1996), dependent on the benthos as a source of food (Beyst et al. 1999, Amara et al. 2001), a change in the availability and distribution of food organisms could change their feeding behaviour, which could affect growth patterns and recruitment. Further expansion of the mussel fishery may also reduce food sources for other filter-feeding organisms. It is important, therefore, that the carrying capacity for mussel cultivation in Swansea Bay should be investigated in order to minimize the impact of mussel lays on the ambient ecosystem.

Acknowledgements. We wish to thank K. Naylor, boatman of the school's vessel, 'Noctiluca'. Thanks also to D. V. Smith, M. R. Lintern and A. Smith for their help in sampling, and to the anonymous referees for their valuable comments on earlier versions of the manuscript. 


\section{LITERATURE CITED}

Amara R, Laffargue P, Dewarumez JM, Maryniak C, Lagardere F, Luczac C (2001) Feeding ecology and growth of 0-group flatfish (sole, dab and plaice) on a nursery ground (Southern Bight of the North Sea). J Fish Biol 58(3): 788-803

Asmus H, Asmus RM (2002) ECSA workshop: Community ecology of soft bottom mussel beds. Helgol Mar Res 56:1-2

Beadman HA, Willows RI, Kaiser MJ (2002) Potential applications of mussel modelling. Helgol Mar Res 56:76 -85

Beyst B, Cattrijsse A, Mees J (1999) Feeding ecology of juvenile flatfishes of the surf zone of a sandy beach. J Fish Biol 55(6):1171-1186

Caldow RWG, Beadman HA, McGrorty S, Kaiser MJ, GossCustard JD, Mould K, Wilson A (2003) Effects of intertidal mussel cultivation on bird assemblages. Mar Ecol Prog Ser 259:173-183

Clark RB, Frid C, Attrill M (1997) Marine pollution, 4th edn. Oxford University Press, Oxford

Clarke KR (1993) Non-parametric multivariate analyses of changes in community structure. Aust J Ecol 18:117-143

Collins M, Ferentinos G, Banner FT (1979) The hydrodynamics and sedimentology of a high (tidal and wave) energy embayment (Swansea Bay, Northern Bristol Channel). Estuar Coast Mar Sci 8:49-74

Commito JA (1987) Adult-larval interactions: predictions, mussels and cocoons. Estuar Coast Shelf Sci 25:599-606

Cowden C, Young CM, Chia FS (1984) Differential predation on marine invertebrates larvae by two benthic predators. Mar Ecol Prog Ser 14:145-149

Dankers N, Zuidema DR (1995) The role of the mussel (Mytilus edulis L.) and mussel culture in the Dutch Wadden Sea. Estuaries 18:71-80

Dolmer P, Frandsen RP (2002) Evaluation of the Danish mussel fishery: suggestions for an ecosystem management approach. Helgol Mar Res 56:13-20

Fish JD, Fish SD (1996) A student's guide to the seashore, 2nd edn. Cambridge University Press, Cambridge

Granby K, Spliid NH (1995) Hydrocarbons and organochlorines in common mussels from the Kattegat and the belts and their relation to condition indices. Mar Pollut Bull 30:74-82

Hayward PJ, Ryland JS (1995) Handbook of the marine fauna of north-west Europe. Oxford University Press, Oxford

Kautsky N, Evans S (1987) Role of biodeposition by Mytilus edulis in the circulation of matter and nutrients in a Baltic coastal system. Mar Ecol Prog Ser 38:201-212

Kröncke I (1996) Impact of biodeposition on macrofaunal communities in intertidal sandflats. PSZN I: Mar Ecol 17: 159-174

Lincoln RJ (1979) British marine Amphipoda: Gammaridea. British Museum (Natural History), London

Luczak C, Janquin M, Kupka A (1997) Simple standard procedure for the routine determination of organic matter in marine sediment. Hydrobiologia 345:87-94

Martin D, Pinedo S, Sarda R (2000) Distribution patterns and

Editorial responsibility: Otto Kinne (Editor),

Oldendorf/Luhe, Germany trophic structure of soft-bottom polychaete assemblages in a north-western Mediterranean shallow-water bay. Ophelia 53:1-17

Mignot J (1996) Physical and biological factors affecting the distribution and abundance of juvenile flatfish in Swansea Bay. PhD thesis, University of Wales Swansea

Moksnes PO (2002) The relative importance of habitat-specific settlement, predation and juvenile dispersal for distribution and abundance of young juvenile shore crabs Carcinus maenas L. J Exp Mar Biol Ecol 271:41-73

Moksnes PO, Pihl L, Montfrans J van (1998) Predation on postlarvae and juveniles of the shore crab Carcinus maenas: importance of shelter, size and cannibalism. Mar Ecol Prog Ser 166:211-225

Morgan SG (1992) Predation by planktonic and benthic invertebrates on larvae of estuarine crabs. J Exp Mar Biol Ecol 163:91-110

Nybakken JM (1993) Marine biology: an ecological approach, 3rd edn. Harper Collins College Publishers, New York

Obert B, Michaelis H (1991) History and ecology of the mussel beds (Mytilus edulis L.) in the catchment area of a Wadden Sea tidal inlet. In: Elliott M, Ducrotoy J (eds) Estuaries and coasts: spatial and temporal intercomparisons. Olsen \& Olsen, Fredensborg, p 185-194

Ragnarsson SA, Raffaelli D (1999) Effect of the mussel Mytilus edulis on the invertebrate fauna of sediments. J Exp Mar Biol Ecol 241:31-43

Saier B (2002) Subtidal and intertidal mussel beds (Mytilus edulis L.) in the Wadden Sea: diversity differences of associated epifauna. Helgol Mar Res 56:44-50

Shackley SE, Collins M (1984) Variations in sublittoral sediments and their associated macro-fauna in response to inner shelf processes; Swansea bay, UK. Sedimentology 31:793-804

Smith J (2002) The effects of the closure of a major sewage outfall on sublittoral, soft sediment benthic communities. $\mathrm{PhD}$ thesis, University of Wales Swansea

Thiel M, Ullrich N (2002) Hard rock versus soft bottom: the fauna associated with intertidal mussel beds on hard bottoms along the coast of Chile, and considerations on the functional role of mussel beds. Helgol Mar Res 56:21-30

Tsuchiya M (1980) Biodeposition production by the mussel Mytilus edulis L. on rocky shores. J Exp Mar Biol Ecol 47: 203-222

Tsuchiya M, Nishihira M (1985) Islands of Mytilus edulis as a habitat for small intertidal animals: effect of island size on community structure. Mar Ecol Prog Ser 25:71-81

Tsuchiya M, Nishihira M (1986) Islands of Mytilus edulis as a habitat for small intertidal animals: effect of Mytilus age structure on the species composition of the associated fauna and community organisation. Mar Ecol Prog Ser 31: 171-178

Widdows J, Lucas JS, Brinsley MD, Salkeld PN, Staff FJ (2002) Investigation of the effects of current velocity on mussel feeding and mussel bed stability using an annular flume. Helgol Mar Res 56:3-12

Submitted: August 22, 2003; Accepted: June 28, 2004

Proofs received from author(s): October 22, 2004 